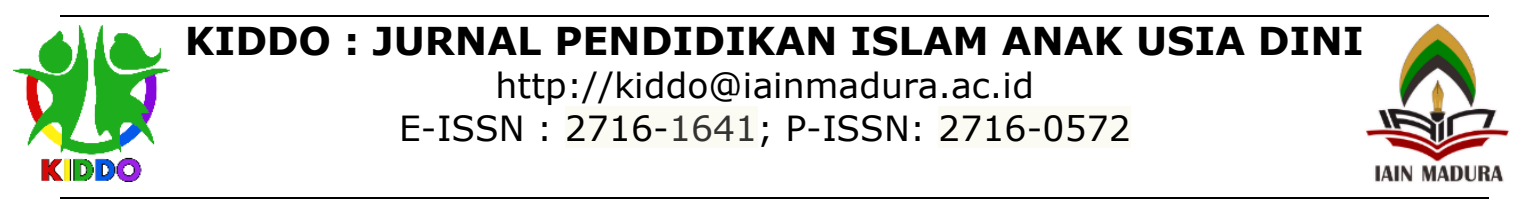

\title{
PROFIL PERKEMBANGAN MOTORIK HALUS PADA PEMBELAJARAN ANAK KELOMPOK A (USIA 4-5 TAHUN) DISENTRA BAHAN ALAM
}

\author{
Mutiara Sari Dewi ${ }^{1}$, Ari Kusuma ${ }^{2}$, Rina Wahyu Hidayati ${ }^{3}$, Anis \\ Susi Adila ${ }^{4}$, Adetya Dwi Selasih ${ }^{5}$ \\ Universitas Islam Malang, Indonesia, \\ mutiara.sari@unisma.ac.id ${ }^{1}$, ari.kusuma@unisma.ac.id ${ }^{2}$, \\ rw8892267@gmai.com ${ }^{3}$, anisadila416@gmail.com", \\ adetyadwi0905@gmail.com ${ }^{5}$
}

\begin{abstract}
The purpose of the research is to find out more clearly the profile of the fine motor development of children in the $A 2$ group dysentery of natural materials. The study population consisted of children from group A RA Muslimat NU 15 totaling 60 children. The sampling technique using purpose sampling produced 23 selected children. This research is a descriptive quantitative research. Data collection techniques used are observation and documentation. The research instruments used in observation 1 . Cut and paste images of foods you like 2. Make bracelets from cassava leaves, 3. Play magic sand to form my favorite objects (toys). Fine motor skills are the skill of using media with coordination between two hands. Fine motor skills of the hands develop the ability of children to use their fingers, especially the thumb and index finger. Fine motor skills in early childhood is very important to be trained, stimulated and developed continuously in accelerating the process of independence of children.
\end{abstract}

\author{
Keywords: \\ Development; \\ Fine motor; \\ Dysentery \\ of natural.
}

\begin{tabular}{lr} 
Abstrak & \\
\hline Penelitian ini bertujuan untuk memaparkan profil & Kata Kunci: \\
perkembangan moto-rik halus anak A2 pada disentra & Perkembangan; \\
bahan alam. Populasi penelitian menggunakan anak & Motorik halus; \\
kelompok A di RA Musli-mat NU 15 sebanyak 60 anak. & Sentra alam. \\
Teknik pengambilan sampel menggunakan purpose & \\
sampling dengan meli-batkan 23 anak terpilih. & \\
Penelitian ini merupakan penelitian kuantitatif & \\
deskriptif. Teknik pengumpulan data yang digunakan & \\
adalah observasi dan dokumen-tasi. Instrumen & \\
penelitian yang digunakan dalam observasi 1. Gambar &
\end{tabular}


potong dan tempel makanan yang disukai 2. Buat gelang dari daun singkong, 3. Permainan pasir ajaib untuk membentuk benda (mainan) kesukaanku. Hasil dari penelitian ini adalah tentang keterampilan motorik halus, yakni keterampil-an menggunakan media dengan koordinasi antara dua tangan. Keterampilan motorik halus pada tangan me-ngembangkan kemampuan anak untuk menggunakan jari-jarinya, terutama ibu jari dan telunjuk. Keteram-pilan motorik halus pada anak usia dini sangat penting untuk dilatih, distimulasi dan dikembangkan terus menerus dalam mempercepat proses kemandirian anak.

Diterima : 20 Nopember 2021; Direvisi: 07 Januari 2021; Diterbitkan: 28 Pebruari 2021

http://doi.org/10.19105/kiddo.v2i1.3939

\section{Pendahuluan}

Pendidikan anak usia dini adalah layanan pendidikan yang diselenggarakan untuk menstimulus perkembangan dan keterampilan yang akan menyokong pendidikan dasar, serta mengembangkan diri secara utuh dengan asas pendidikan sedini mungkin dan sepanjang hayat. Lima aspek perkembangan yang dikembangkan dalam layanan penyelenggara pendidikan anak usia dini adalah perkembangan sosial, emosional, nilai-nilai dan moral agama, pengembangan kemampuan dasar yakni pengembangan kemampuan verbal atau bahasa, kognitif, dan fisik motorik. Khusus perkembangan fisik motorik, meliputi: fisik motorik kasar dan fisik motorik halus (Masfiroh, 2008).

Masa anak-anak adalah masa otak menyerap. Informasi apa saja akan terekam pada otaknya melalui indera. Stimulus dari luar berupa kata-kata dan atau gerak gerik akan direkam anak, karena perkembangan otak yang mencapai $80 \%$. Bisa jadi pada saat bayi, anak-anak belum bias mengekspresikan apa yang dilihat, namun Ketika besar nanti, apa yang telah direkam anak akan dilakukannya. Perilaku atau social emosional orang sekitar yang kesemua dari hal tersebut melibatkan otak dan gerakan tubuh anak (Suyanto, 2005). Pada rentang usia seperti ini, merupakan fase fundamental yang akan menentukan kehidupannya dimasa datang. Apa yang telah dilihat dan ditiru oleh anak akan terekam hingga dewasa. Oleh sebab itu kita harus memahami perkembangan anak usia dini khususnya perkembangan fisik dan motorik, sehingga dapat dengan tepat menentukan stimulusnya. Menurut Cambridge shire Community Services NHS (2018) keterampilan motorik halus merupakan kelanjutan kekuatan otot dari gerak terkontrol motoik kasar pada bagian-bagian tangan. Sebelum anak-anak terlatih motorik halusnya, terlebih dahulu motorik kasarnya yang berkembang. Keterampilan motorik halus melibatkan otot-otot pada tubuh. Keterampilan motorik 
halus adalah pelibatan dari kekuatan serta control otot tangan, dengan pengaruh koordinasi mata otak, dan sentuhan jari-jemari.

Anak yang memiliki keterampilan motorik halus yang baik lebih mudah mengeksplor lingkungan. Tentu saja hal ini sangat bermanfaat dalam proses pendidikan, dengan kemampuan motorik halus yang telah berkembang, memungkinkan anak-anak untuk menyenangi aktivitas tertentu sejak dini. Anak yang memiliki rentang usia 4 sampai 5 tahun memiliki energy yang lebih. Energi ini dapat dilepas melalui aktivitas yang bermacam-macam. Tentu saja dengan banyaknya gerak, anak-anak dapat mengeksplor lingkungan dengan cara meraba, mencium atau lainnya yang menggunakan kepekaan indra, sehingga dapat meningkatkan aspek perkembangan anak terutama keterampilan fisik motorik halus yang berkaitan dengan aktivitas menggunting dan menempel kertas, membentuk sesuatu dengan pasir atau plastisin, menggambar, mewarna, memotong kertas, merangkai benda dengan benang (meronce), yang termasuk aktivitas pada sentra seni/ bahan alam. Aktivitas keterampilan motorik halus anak bertujuan untuk mensetimulus koordinasi otot-otot halus pada jari-jemari dengan otak dan mata yang dapat dikembangkan melalui kegiatan bermain (Sumantri, 2005). Salah satu kunci keberhasilan pembelajaran pada anak usia dini adalah guru yang mampu memerankan sebagai pembaharu, motivator, inovator, sertadapatberinovasidenganalatpermainanedukatifdalampembelajaran.

Berdasarkanpengamatan di RA MUSLIMAT NU 15 Sukun Malang, keterampilan motorik halus kelompok $A$ masih belum begitu berkembang. Ada beberap aanak yang menunjukkan keterlambatan dalam keterampilan motorik halus, terutama pada aktivitas menggunting dan menempel, begitu juga denganmembentuk suatu pola yang sesuai .Tetapi ada juga anak yang sudah bisamengikuti apa yang dicontohkan guru. Hal ini disebabkan oleh kemampuan dan karakteristik anak yang berbeda, sehingga perlu adanya stimulus yang berkelanjutan guna perkembangan yang optimal.

Dari permasalahan tersebut diatas, maka diadakan penelitian yang berhubungan dengan pengembangan motorik halus yang dapat menstimulus perkembangan anak usia dini sesuai dengan tahap-tahap perkembangan.

\section{Metode Penelitian}

Penelitian ini adalah penelitian kuantiatif deskriptif. Menurut Moleong (2014: 6), penelitian kualitatif adalah penelitian yang dimaksudkan untuk memahami fenomena tentang apa yang dialami oleh subjek penelitian misalnya perilaku, motivasi, tindakan, dll. yang dilakukan di RA Muslimat NU 15, Kecamatan Sukun selama 1,5 (satu setengah) bulan. Populasi penelitian yaitu anak kelompok A RA Muslimat NU 15 berjumlah 60 anak. Teknik pengambilan sampel menggunakan purposive sampling yang menghasilkan 23 anak terpilih menjadi sampel penelitian. Teknik pengumpulan data yang digunakan ada penelitian ini adalah observasi dan dokumentasi. Teknik analisis 
data menggunakan analisis dekskriptif dengan presentase untuk mengetahui profil perkembangan social anak kelompok $A$.

\section{Hasil dan Pembahasan}

Hasil penelitian profil motorik halus anak kelompok A2 di RA muslimat NU 15. Penelitian ini merupakan penellitian deskriptif, sehingga hasil penellitian tentang profil motorik halus anak kelompok A2 RA Muslimat NU 15, adapun hasil penelitian setiap indikator diperoleh data sebagai berikut:

Tabel1. Distribusi Frekuensi Motorik Halus Anak Kelompok A2 dalam Indikator Menggunting dan Menempel Gambar Makanan yang di Sukai

\begin{tabular}{|c|c|c|c|}
\hline $\begin{array}{c}\text { Kelas } \\
\text { Penelitian }\end{array}$ & Kriteria Penelitian & Frekuensi & Presentase \\
\hline$\hat{\aleph} 1$ & $\begin{array}{l}\text { Anak belum mau } \\
\text { mengerjakan pekerjaan }\end{array}$ & 1 & $4,3 \%$ \\
\hline$\dot{\hbar} \aleph^{2}$ & $\begin{array}{l}\text { Anak mampu } \\
\text { menggunting dan } \\
\text { menempel tetapi belum } \\
\text { rapi }\end{array}$ & 1 & $4,3 \%$ \\
\hline 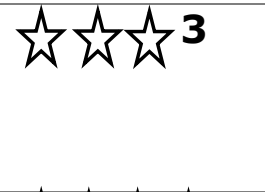 & $\begin{array}{l}\text { Anak mampu menempel } \\
\text { gambar dengan sesuai } \\
\text { tetapi dalam hal } \\
\text { menggunting belum rapi }\end{array}$ & 14 & $60,8 \%$ \\
\hline 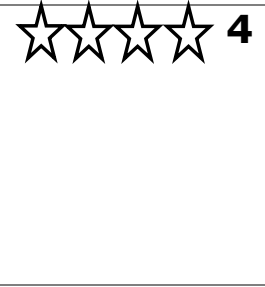 & $\begin{array}{lr}\text { Anak } & \text { mampu } \\
\text { menggunting } & \text { dan } \\
\text { menempel } & \text { gambar } \\
\text { makanan yang disukai } \\
\text { dengan rapi dan sesuai } \\
\text { perintah }\end{array}$ & 7 & $30,5 \%$ \\
\hline
\end{tabular}

Berdasarkan table tersebut tampak bahwa perkembangan motorik halus anak dalam hal mengerjakan perkerjaan seperti menggunting dan menempel makanan kesukaan yaitu anak belum mau mengerjakan pekerjaan: 1 anak $(4,3 \%)$ anak mau mengerjakan tetapi tidak sesuai dengan perintah dan masih perlu bimbingan guru: 1 anak $(4,3 \%)$ anak mau mengerjakan sesuai perintah tetapi kurang rapi: 14 anak $(60,8 \%)$ anak mau mengerjakan dengan sesuai perintah dan mandiri: 7 anak $(30,5 \%)$. Frekuensi terbanyak terletak pada kategori anak mau mengerjakan sesuasi perintah tetapi kurang rapi.

Tabel 2. Distribusi frekuensi motorik halus Anak Kelompok A2 dalam Indikator Membuat Gelang dari Batang Daun Singkong

\begin{tabular}{llcc}
\hline Kelas Penelitian & \multicolumn{1}{c}{ Kriteria Penelitian } & Frekuensi & Presentase \\
\hline \multirow{1}{1}{$\mathbf{1}$} & $\begin{array}{l}\text { Anak belum mau } \\
\text { mengerjakan pekerjaan }\end{array}$ & 2 & $8,7 \%$ \\
\hline $\boldsymbol{h}^{2}$ & Anak mampu & 10 & $43,5 \%$ \\
\hline
\end{tabular}




\begin{tabular}{lll}
\hline & $\begin{array}{l}\text { mengerjakan tetapi } \\
\text { masih perlu bimbingan } \\
\text { dan belum sesuai } \\
\text { perintah }\end{array}$ & \\
& $\begin{array}{l}\text { Anak mampu } \\
\text { mengerjakan tetapi } \\
\text { masih dibantu dalam hal } \\
\text { mengikat batang daun } \\
\text { singkong pada } \\
\text { pergelangan tangan } \\
\text { anak }\end{array}$ & \\
& $\begin{array}{l}\text { Anak sudah mandiri } \\
\text { dapat membentuk } \\
\text { gelang dari batang daun } \\
\text { singkong dan } \\
\text { mengikatkan pada } \\
\text { pergelangan tangan } \\
\text { anak }\end{array}$ & \\
\end{tabular}

Berdasarkan table tersebut tampak bahwa perkembangan motorik halus anak dalam hal mengerjakan perkerjaan seperti membuat gelang dengan batang daun singkong yaitu: Anak belum mau mengerjakan pekerjaan: 2 anak (8,7\%), Anak mampu mengerjakan tetapi masih perlu bimbingan dan belum sesuai perintah: 10 anak $(43,5) \%$, Anak mampu mengerjakan tetapi masih dibantu dalam hal mengikat batang daun singkong pada pergelangan tangan anak: 7 anak $(30,5) \%$, Anak sudah mandiri dapat membentuk gelang dari batang daun singkong dan mengikatkan pada pergelangan tangan anak: 4 anak $(17,4 \%)$

\begin{tabular}{|c|c|c|c|}
\hline $\begin{array}{c}\text { Kelas } \\
\text { penelitian }\end{array}$ & Kriteria Penelitian & Frekuensi & Presentase \\
\hline$\hat{h} 1$ & $\begin{array}{l}\text { Anak belum mau } \\
\text { mengerjakan pekerjaan }\end{array}$ & 1 & $4,3 \%$ \\
\hline$\hbar^{n} \hbar^{2}$ & $\begin{array}{l}\text { Anak mampu mengerjakan } \\
\text { tetapi masih perlu bantuan } \\
\text { dan pemahaman berulang- } \\
\text { ulang dari guru }\end{array}$ & 6 & $26,1 \%$ \\
\hline 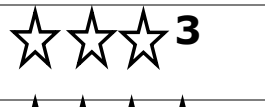 & $\begin{array}{l}\text { Anak mampu mencetak pasir } \\
\text { tetapi masih belum rapi }\end{array}$ & 9 & $40 \%$ \\
\hline 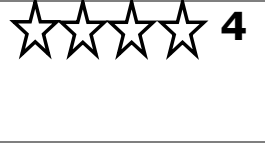 & $\begin{array}{l}\text { Anak mampu mencetak pasir } \\
\text { tanpa bantuan guru dan } \\
\text { sudah rapi }\end{array}$ & 7 & $30,5 \%$ \\
\hline
\end{tabular}


Berdasarkan table tersebut tampak bahwa perkembangan motorik halus anak dalam hal mengerjakan perkerjaan seperti Bermain pasir ajaib membentuk benda kesukaanku (mainan) yaitu: 1 anak $(4,3 \%)$ Anak belum mau mengerjakan pekerjaan, 6 anak $(26,1 \%)$ Anak mampu mengerjakan tetapi masih perlu bantuan dan pemahaman berulang-ulang dari guru, 9 anak (40\%) Anak mampu mencetak pasir tetapi masih belum rapi, 7 anak (30,5\%) Anak mampu mencetak pasir tanpa bantuan guru dan sudah rapi.

Berdasarkan hasil penelitian diatas menunjukkan bahwa profil perkembangan motorik halus anak kelompok A RA Muslimat NU 15, Malang berkategori sedang atau (3). Hal ini terlihat bahwa terdapat 30 anak mendapat (3) dengan beberapa indikator yaitu: 1) Anak mampu menempel gambar dengan sesuai tetapi dalam hal menggunting belum rapi. 2) Anak mampu mengerjakan tetapi masih dibantu dalam hal mengikat batang daun singkong pada pergelangan tangan anak. 3) Anak mampu mencetak pasir tetapi masih belum rapi. Ketiga indicator tersebut.

Hal tersebut sesuai dengan pendapat Sujiono (2009) yang menyatakan bahwa gerakan motorik halus adalah apabila gerakan hanya melibatkan bagian-bagian tubuh tertentu saja dan dilakukan oleh otot-otot kecil. Anak-anak harus distimulus otot-otot kecilnya dengan aktivitas seperti keterampilan menggunakan jari-jemari tangan atau gerakan pergelangan tangan yang tepat. Dengan begitu, kemampuan menulis dan kekuatan otot untuk pendidikan selanjutnya sangat berguna. Sejalan dengan pendapat dari Lerner (dalam Sunardi; 2007), gerak ,motorik halus merupakan keterampilan menggunakan media dengan koordinasi antara dua tangan. Kemampuan motorik halus tangan mengembangkan kemampuan anak dalam menggunakan jari-jarinya khususnya ibu jari dan jari telunjuk, karena dua jari tersebut sumber dari kekuatan tangan.

Berdasarkan observasi dan dokumentasi yang diperoleh, 16 anak berada pada kategori (2) yang disebabkan oleh pendidik dan orang tua yang sering dibantu mengerjakan dirumah.

\section{Kesimpulan}

Berdasarkan penelitian diatas dapat disimpulkan bahwa kemampuan motorik halus pada anak usia dini sangat penting untuk dilatih, distimulus dan dikembangkan secara terus-menerus dalam mempercepat proses kemandirian anak dan sebagai bekal untuk kehidupan dimasa yang akan dating baik dilingkungan sekolah maupun dilingkungan masyarakat anak merasa percaya diri dengan kemampuan motorik halus yang sudah terlatih dengan baik.

\section{Saran}

Sebagai orang tua dan guru diharapkan dapat membantu mengembangkan kemampuan motorik halus pada diri anak agar nantinya dapat berguna dimasa mendatang. 


\section{Daftar Pustaka}

Ali Nugraha,dkk. (2003). Kiat Merangsang Kecerdasan Anak. Jakarta: Puspa Swara.

Anggraheni, Ika. (2019). Profil Perkembangan Motorik Halus dan Kreativitas Anak Kelompok B dalam Kegiatan Cooking Class. Thufula: Jurnali Imiah Pendidikan Islam Anak usia Dini. 1(2) hal.2-6.

Askandari, L. Peningkatan Kemampuan Motorik Halus Melalui Pembelajaran Melukis Dengan Jari Pada Anak Usia 5-6 Tahun. (online). http://jurnal.untad.ac.id

Cambridgeshire Community Services NHS. (2018). Fine Motor Skills Children's Therapy Services. (online) https://www.cambscommunityservices.nhs.uk

Labonati, R. (tt). Meningkatkan Kemampuan Motorik Halus Anak Melalui Metode Pemberian Tugas Pada Kelompok B Di Tk AlKhairaat Lolu. Jurnal Bungamputi Untad. 2(2)

Masitoh,dkk. (2004). Strategi Pembelajaran TK. Buku Materi Pokok. Jakarta: Penerbit Universitas Terbuka.

Mely. (2013). Hakikat Perkembangan Motorik Halus Anak Usia Dini. (Online).http://melyloelyhabox.blogspot.com/2013/05/hakikatpengembangan-motorik-anak -tk.html?m=1), diakses 17 September 2019.

Moeslichatoen. (2004). Metode Pengajaran di TK. Jakarta: Rineka Cipta.

Mulyasa. (2013). Manajemen PAUD. Bandung: PT.Remaja Rosdakarya. Indeks Jakarta.

Novan Ardi Wiyani. (2013). Bina Karakter Anak Usia Dini: Panduan Orang Tua dan Guru Dalam membentuk Kemandirian dan Kedisiplinan Anak Usia Dini. Yogyakarta: Ar-Ruzz Media.

Novan, Ardi.(2015). Manajemen Paud Bermutu: Konsep dan Praktik MMT di KB, TK/RA. Yogyakarta: Gava Media.

Susanti, Ria, dkk. (2016). Enam Cara Pengembangan Motorik Halus Anak Melalui Metode Pemberian Tugas. (Online) http://www.sciencedirect.com. Diakses tanggal 20 september 2019.

Sujiono, N. Y. (2009). Konsep Dasar Pendidikan Anak Usia Dini. Jakarta: Gramedia Pustaka. 
Sunardi \& Sunaryo. (2007). Intervensi Dini Anak Berkebutuhan Khusus. Jakarta: Depdiknas Dirjen Penti Direktorat Ketenagaan. 